\title{
Sediment bacteria and archaea community analysis and nutrient fluxes in a sub-tropical polymictic reservoir
}

\author{
Timothy J. Green ${ }^{1, *}$, Andrew C. Barnes ${ }^{1}$, Michael Bartkow ${ }^{2}$, Deb Gale ${ }^{2}$, \\ Alistair Grinham ${ }^{3}$ \\ ${ }^{1}$ School of Biological Sciences, The University of Queensland, Brisbane, Queensland 4072, Australia \\ ${ }^{2}$ Queensland Bulk Water Supply (trading as Seqwater), 240 Margaret Street, Brisbane, Queensland 4000, Australia \\ ${ }^{3}$ Centre for Water Studies, School of Civil Engineering, The University of Queensland, Brisbane, Queensland 4072, Australia
}

\begin{abstract}
Lake sediments are important areas for remineralisation of nutrients involved in phytoplankton blooms. This study simultaneously analysed the microbial community structure and measured the sediment fluxes of inorganic nitrogen, phosphorus and silica from sediment cores collected at 2 different locations within a sub-tropical polymictic reservoir, Lake Wivenhoe. The bacterial and archaeal community structure was determined by amplifying and cloning the 16S rRNA gene from co-extracted DNA and RNA samples. A total of 19 phyla or candidate divisions of bacteria were identified, with sulphur-reducing bacteria within the phylum of Deltaproteobacteria being the most abundant ribotypes in DNA-derived clones libraries. In contrast, Actinobacteria and Acidobacteria were the most abundant ribotypes in RNA-derived clone libraries from the upper and lower sediments, respectively. The archaeal community was dominated by Euryarchaeota, with methanogenic archaea belonging to subdivisions of Methanobacteria and Methanomicrobia accounting for 69 to $98 \%$ of the sequenced clones. Comparison of the 16S rDNA and rRNA clone libraries revealed that bacterial groups highly abundant in the sediments were mostly metabolically inactive, whilst those metabolically active were not very abundant. A higher relative abundance of nitrifying ribotypes (Nitrospira sp.) was identified at Site B, which corresponded to a higher efflux of nitrate from the sediments to the water column at this site. At the time of sampling, Lake Wivenhoe was stratified, and sediment cores were collected from the hypolimnion. Our results suggest that water column depth and delivery of dissolved oxygen to the sediments influenced the sediment microbial community structure and the fluxes and speciation of nutrients, which are reported to influence phytoplankton species composition and bloom dynamics.
\end{abstract}

KEY WORDS: Microbial community $\cdot$ Sediment $\cdot$ Nutrients $\cdot$ Bacteria $\cdot$ Archaea $\cdot 16 \mathrm{~S}$ rRNA

\section{INTRODUCTION}

Sediments in shallow water bodies are important areas of nutrient remineralisation and carbon processing and are also depositional zones. The large surface area generated by the sediment grains and strong gradients in organic substrates and terminal electron acceptors provide an ideal environment for exploitation by many different microbial groups (Schwarz et al. 2007). Many of the microorganisms within the sediments play key roles in biogeochemical cycling of carbon, nitrogen, phosphorus and silica. In shallow lakes, these biogeochemical processes greatly influence phytoplankton blooms and water quality because of the intensive interchange of nutrients between the sediments and water column (Ye et al. 2009). 
Lake Wivenhoe is the largest water storage reservoir in south-eastern Queensland and supplies 80\% of the drinking water of the city of Brisbane, Australia (Douglas et al. 2007). The lake is eutrophic and suffers from frequent blooms of toxic Cyanobacteria and periodic episodes of earthy odours (geosmin or 2methylisoborneol), likely produced by either Cyanobacteria or Actinomycetes (Klausen et al. 2004, Zaitlin \& Watson 2006). Research on phytoplankton bloom formation and sources of nutrients is currently underway in Lake Wivenhoe in an attempt to improve the quality of the water for drinking (Burford et al. 2012, Kerr et al. 2010, 2011a,b). Nitrogen and phosphorus are the 2 most important nutrients governing phytoplankton growth (Correll 1998). However, differences in the ratios of dissolved N:P:Si can change phytoplankton species composition within a lake because the growth of diatom species depends on the presence of dissolved silica, whereas the growth of non-diatom phytoplankton species (e.g. Cyanobacteria) does not (Conley et al. 1993).

Lake Wivenhoe is considered to be a polymictic lake because it experiences several periods of thermal stratification, separated by periods of overturn and fully mixed conditions, each year. During thermal stratification, the hypolimnion becomes anoxic from the biodegradation of organic material in the sediments by oxygen-consuming microorganisms. During anoxic conditions, ammonia is one of the first compounds to be released from the sediments as the biological oxidation of ammonia to nitrate (nitrification) is inhibited (Beutel et al. 2008), and the biological uptake of ammonia in anoxic conditions is relatively low compared to aerobic conditions (Beutel 2006). The sediments of lakes with oxic hypolimnia contain oxidized iron $\left(\mathrm{Fe}^{3+}\right)$ as $\mathrm{Fe}\left(\mathrm{PO}_{4}\right)$ and related hydroxides (Murray 1995). As the dissolved oxygen further decreases, $\mathrm{Fe}^{3+}$ is reduced, and $\mathrm{Fe}^{2+}$ and $\mathrm{PO}_{4}{ }^{3-}$ are released into the water column (Murray 1995). Ammonia and phosphorus released into bottom waters from the sediments can exacerbate eutrophication when bottom waters mix with surface waters (Beutel et al. 2008). Ammonia is the preferred nitrogen source for the local toxic Cyanobacteria, Cylindrospermopsis raciborskii (Burford et al. 2006), and pulses of $\mathrm{PO}_{4}{ }^{3-}$ were also shown to promote C. raciborskii dominance of the phytoplankton community (Posselt et al. 2009). Remineralisation rates of silica contained in diatom frustules within the sediments are largely controlled by physiochemical processes, such as the degree of under-saturation of dissolved silica in the water or the blocking of reactive sites by inhibitors, such as metal ions (Conley et al. 1993). However, prokaryotes can enhance the dissolution of biogenic silica by removing organic coatings from diatom frustules and thereby enhancing the amount of 'clean' surface area exposed to under-saturated waters (Libes 2009).

The identification of the microorganisms within the sediments of Lake Wivenhoe is a key step towards understanding how N, P and Si are remineralised within this ecosystem. Thus, clone libraries of polymerase chain reaction (PCR)-amplified bacterial and archaeal 16S ribosomal genes from sediment samples were sequenced, and the potential biological and metabolic process of each microorganism within the clone library was inferred from the phylogenetic position of its sequence. Putative metabolic processes performed by sediment microbes were then compared to nutrient fluxes of dissolved N, P and Si. Because a large fraction of the microbial cells within the anoxic sediments may be dormant or dead (see Miskin et al. 1999), the relative abundances of ribotypes in clone libraries prepared from either DNA or RNA were compared to identify the active microbial fraction. Our results provide insight into biogeochemical processes occurring within the sediments of Lake Wivenhoe and the prokaryotes responsible for remineralisation of nutrients in the sediments.

\section{MATERIALS AND METHODS}

\section{Study sites, sampling, core incubations and nutrient fluxes}

Sediment cores were collected from 2 different locations (Site A, $27^{\circ} 19.59 \mathrm{~S}, 152^{\circ} 33.10 \mathrm{E}$, and Site B, $\left.27^{\circ} 20.40 \mathrm{~S}, 152^{\circ} 32.46 \mathrm{E}\right)$ within Lake Wivenhoe, SE Queensland, Australia. This slightly alkaline lake is shallow (the average depth is $10 \mathrm{~m}$ ), with a surface area of 10940 ha at full capacity (Douglas et al. 2007). The 2 sites chosen were known to differ in both physical (e.g. temperature and depth) and chemical (e.g. dissolved inorganic nitrogen and $\mathrm{pH}$ ) parameters, based on routine water quality monitoring conducted on the lake by Seqwater. The physicochemical profile of each sampling site was determined at the time of sampling using a multi-parameter YSI 6600 V2 data sonde to measure dissolved oxygen, temperature and $\mathrm{pH}$ at $1 \mathrm{~m}$ increments. Three replicate sediment cores were collected from each site using a gravity corer fitted with acrylic liners (diameter $65 \mathrm{~mm}$ and length $400 \mathrm{~mm}$ ), and 100 to $150 \mathrm{~mm}$ of sediment covered by $\sim 300 \mathrm{~mm}$ of water was collected. Cores were capped with an airtight bung and transported to the laboratory $(<2 \mathrm{~h})$, where they were 
immediately placed in incubators filled with water from each site that had been passed through a $60 \mu \mathrm{m}$ mesh screen. The incubator water was maintained at the measured ambient temperature (Site A $19 \pm 1^{\circ} \mathrm{C}$ and Site B $20 \pm 1^{\circ} \mathrm{C}$ ), and dark conditions were imposed because the sediment cores were collected from the aphotic zone. The water column within each core was gently mixed using a Teflon-coated magnetic stirrer positioned below the core cap at a rate that avoided sediment re-suspension. The cores were left overnight to settle, and incubations began when the dissolved oxygen returned to ambient levels ( 0.35 and $0.55 \mathrm{mg} \mathrm{l}^{-1}$ at Site A and B, respectively). The sediment fluxes of dissolved inorganic nitrogen species $\left(\mathrm{NH}_{4}{ }^{+}, \mathrm{NO}_{2}{ }^{-}\right.$and $\left.\mathrm{NO}_{3}{ }^{-}\right)$, filterable reactive phosphorus (FRP), total phosphorus (TP) and reactive silica were estimated by withdrawing water using a plastic syringe at $6 \mathrm{~h}$ intervals over a $24 \mathrm{~h}$ period from the sample port located in the incubator core cap. Water samples were filtered $(0.45 \mu \mathrm{m})$, frozen at $-20^{\circ} \mathrm{C}$ and subsequently assayed for the above parameters colourimetrically using a flow injector analyser by Queensland Health, Forensic \& Scientific Services. Dissolved methane fluxes were estimated by withdrawing $6 \mathrm{ml}$ of each water sample from the sample port and analysing the methane content using a gas chromatograph as described by O'Sullivan et al. (2005). Fluxes of methane, silica, nitrogen and phosphorus species across the sediment-water interface were calculated by linear regression of the concentration data as a function of time, core water volume and surface area (Eyre \& Ferguson 2002).

At the end of the incubations, sediment samples from the upper (0 to $50 \mathrm{~mm}$ ) and lower sediments (100 to $150 \mathrm{~mm}$ ) were taken using a sterile serological pipette from one core per site. Sediment samples were immediately frozen in liquid nitrogen and stored at $-80^{\circ} \mathrm{C}$ for subsequent nucleic acid extraction.

\section{Co-extraction of RNA/DNA and PCR amplification}

Total genomic DNA and total RNA were coextracted from sediment core samples using the RNA PowerSoil $^{\mathrm{TM}}$ Total RNA Isolation kit and the DNA Elution Accessory kit (Mo Bio Laboratories). The purified total RNA was DNAse treated using the RNeasy mini kit with the RNase-Free DNase set (Qiagen), and $200 \mathrm{ng}$ of total RNA per sample was reverse-transcribed using the Superscript ${ }^{\circledR}$ III FirstStrand Synthesis System (Invitrogen). Community ribosomal DNAs or cDNAs were PCR amplified in 3 parallel $25 \mu \mathrm{l}$ PCR reactions using Platinum ${ }^{\circledR}$ Taq DNA Polymerase High Fidelity (Invitrogen) and $300 \mathrm{nM}$ of each of the universal bacterial primers 27F (5'-AGA GTT TGA TCC TGG CTC AG-3') and 1492R (5'-GTT ACC TTG TTA CGA CTT-3') or universal archaeal primers 109aF (5'-ACK GCT CAG TAA CAC GT-3') and 1119aR (5'-GGY RSG GGT CTC GCT CGT T-3'). Replicate amplification products were pooled to account for PCR bias, purified using a NucleoSpin ${ }^{\circledR}$ Extract II kit (Macherey-Nagel) and cloned using the $\mathrm{pCR} 4{ }^{\circledR}$ TOPO cloning kit (Invitrogen). The PCR inserts from 95 positive clones from each library were amplified using PCR and forward sequenced using gene specific primers $(27 \mathrm{~F}$ or 109aF) by the Australian Genome Research Facility. High quality partial sequences were aligned using ClustalW to allow the identification of identical or nearly identical sequences, and 114 bacterial and 92 archaeal clones were selected for complete sequencing using M13F and M13R primers as above.

\section{Phylogenetic analysis}

The obtained sequences were quality scored and visually checked for possible sequencing errors before compilation using Sequencher version 4.9 (Gene Codes Corporation). The sequences were then compared to the available databases using the basic local alignment search tool (BLAST) network service (Altschul et al. 1997) to determine their approximate phylogenetic affiliations. Chimeric sequences were identified and removed from further analysis using Bellerophon (Huber et al. 2004) and Mallard (Ashelford et al. 2006). Sequences were then aligned with selected reference 16S rRNA sequences from GenBank using the ClustalW algorithm in Mega version 4.0 (Tamura et al. 2007), and phylogenetic trees were constructed using the neighbour-joining distance method (Saitou \& Nei 1987). The statistical significance of interior nodes was determined by performing bootstrap analyses based on 1000 re-samplings of the data. Sequences described in this study were submitted to GenBank and assigned accession numbers from HQ330530 to HQ330736.

\section{Identification of ammonia-oxidising archaea and bacteria}

The alpha-subunit of the ammonia monooxygenase $(a m o A)$ gene was PCR amplified from genomic DNA and cDNA in an attempt to determine the bac- 
teria and archaea responsible for ammonia oxidation within the sediments. The archaeal amoA gene was amplified using the primers Arch-amoAF (5'-STA ATG GTC TGG CTT AGA CG-3') and Arch-amoAR (5'-GCG GCC ATC CAT CTG TAT GT-3') following the PCR conditions described by Francis et al. (2005). The bacterial amoA gene was amplified using the primers amoA-1F (5'-GGG GTT TCT ACT GGT GGT-3') and amoA-2R (5'-CCC CTC KGS AAA GCC TTC TTC-3') following similar PCR conditions described by Rotthauwe et al. (1997). Duplicate PCR products were pooled, purified (QIAquick PCR Purification kit, Qiagen) and visualised on a $1 \%$ agarose/ethidium bromide gel alongside a $1 \mathrm{~kb}$ DNA ladder (Fermentas).

\section{RESULTS}

\section{Water column profile and sediment flux of nutrients}

Strong gradients in water temperature, dissolved oxygen concentration and $\mathrm{pH}$ were observed at both Sites A and B (Fig. 1). The depth at Site A and B was 29 and $15 \mathrm{~m}$, respectively. The concentration of dissolved oxygen, $\mathrm{pH}$ and temperature was measured directly $(0.5 \mathrm{~m})$ above the water/sediment interface, and these parameters were found to be marginally lower at Site A (Fig. 1).

The daily flux of nutrients from sediment cores is presented in Fig. 2. A greater efflux of silica was observed from sediment cores collected from Site A
(Fig. 2). Ammonia fluxes differed between sampling sites, with a strong efflux of ammonia observed in cores collected from Site A, whilst a slight influx of ammonia was observed in sediment cores from Site B (Fig. 2). Patterns of nitrate and nitrite fluxes were similar between sites; however, the flux rates differed greatly, with the nitrate efflux almost 3-fold greater at Site $\mathrm{B}$, whilst the nitrite influx was over 5-fold lower. The concentration of $\mathrm{NH}_{4}{ }^{+}, \mathrm{NO}_{3}{ }^{-}$and FRP measured in the bottom waters was in accordance with differences in flux rates from sediment cores collected from Sites A and B (data not shown). A strong efflux of methane was also measured from sediment cores (Fig. 3), with the methane flux almost 4 -fold greater from sediment cores collected from Site A.

\section{Bacterial community analysis}

A total of 570 bacterial clones were randomly selected for sequencing from 4 bacterial 16S rDNA and 2 bacterial 16S rRNA clone libraries (95 clones per library), which resulted in 476 high quality partial sequences for further analysis. These partial sequences were clustered into 114 groups, and representatives from each group were forward- and reverse-sequenced, yielding 87 identified operational taxonomic units (OTUs), based on a $97 \%$ cutoff. A total of 14 chimeric sequences were detected and deleted from analysis. The number of clones analysed per library is presented in Table 1. Rarefaction analysis of the 6 samples (Fig. 4) indicated that sampling did not reach a diversity asymptote based on $97 \%$ similarity clustering. Less than $40 \%$ of the $16 \mathrm{~S}$ rRNA gene sequences in the current study were affiliated with already existing sequences in the public database with $97 \%$ identity (see Table S1 in the supplement at www. int-res.com/articles/suppl/a065p287 _supp.pdf). These 16S rRNA gene sequences had high similarities to those of uncultured environmental prokaryotes retrieved from a phreatic sinkhole (Sahl et al. 2010), wetlands (D'Auria et al. 2010) and lake (Briée et al. 2007, Schwarz et al. 2007, Ye et al. 2009) and estuarine sediment (Jiang et al. 2009). The remaining sequences were remotely related to $16 \mathrm{~S}$ rRNA gene sequences of known bacteria and represent novel phylotypes not described in previous studies.
Fig. 1. Physiochemical profile of the water column measured at $1.0 \mathrm{~m}$ increments prior to core collection at Site A (continuous line) and Site B (dashed line). Sediment depths (thick horizontal grey lines) were $29 \mathrm{~m}$ (Site A) and $15 \mathrm{~m}$ (Site B) 

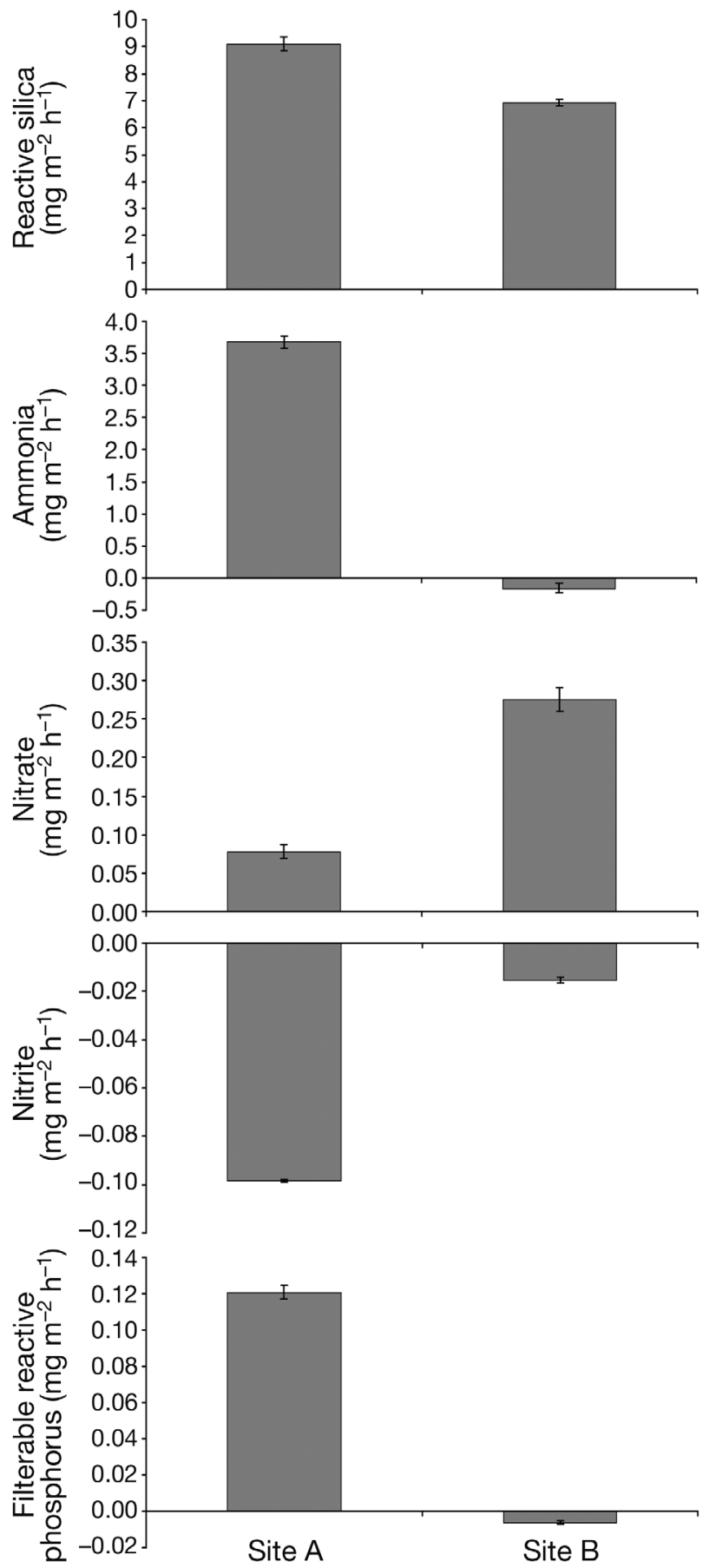

Fig. 2. Sediment nutrient fluxes of dissolved inorganic silica, nitrogen and phosphorus species from sediment cores collected at Sites A and B. Means \pm SE are shown

Phylogenetic analysis (Figs. 5, 6 \& 7) indicated that the bacterial community of the sediments within Lake Wivenhoe consisted of Alpha-, Beta-, Delta- and Gammaproteobacteria, Acidobacteria, Actinobacteria, Bacteroidetes, Chlorobi, Chloroflexi,

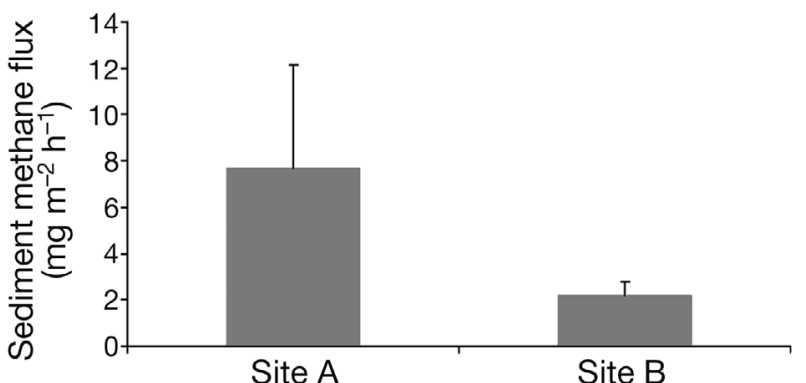

Fig. 3. Methane flux rates from sediment cores collected at Sites $\mathrm{A}$ and B. Means $\pm \mathrm{SE}$ are shown

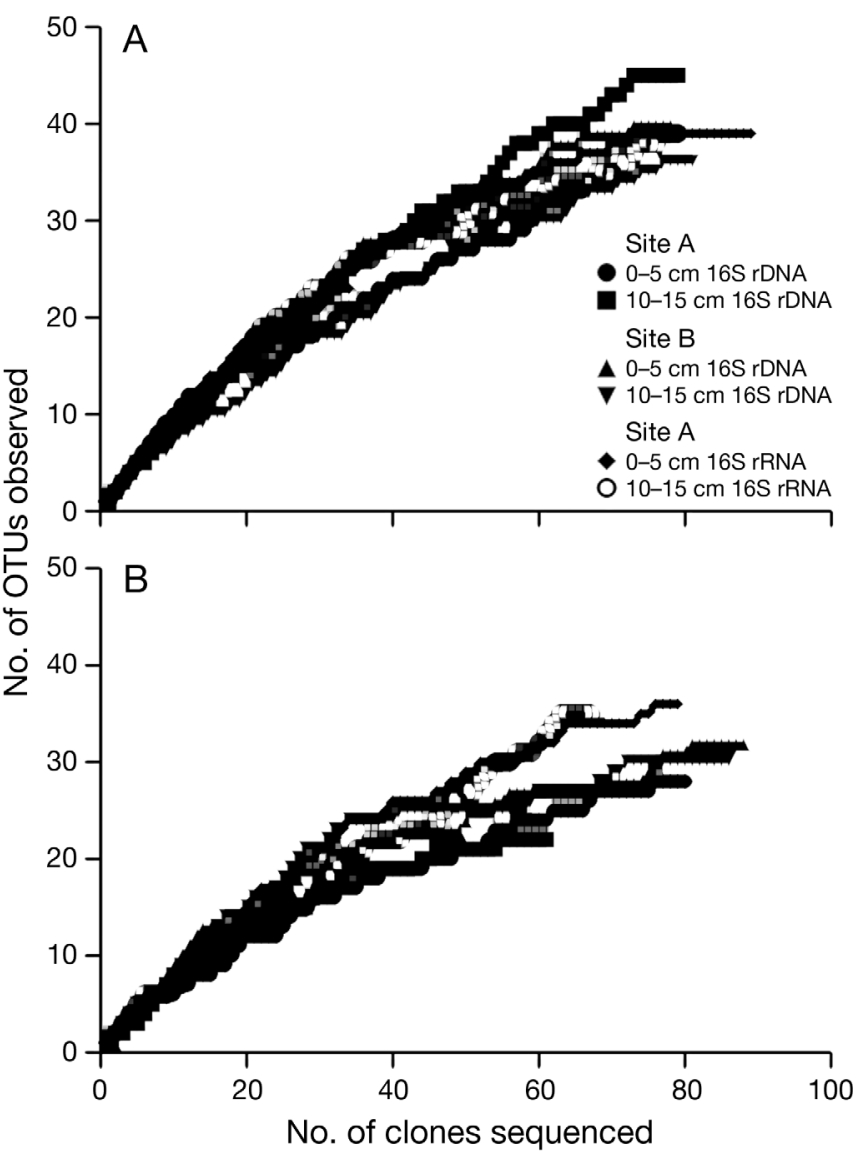

Fig. 4. Rarefaction curves based on $97 \%$ similarity of (A) bacterial and (B) archaeal clone libraries. Libraries were generated from either genomic DNA (16S rDNA) or total RNA (16S rRNA) at Site A, whereas libraries at Site B were only generated from genomic DNA. OTU: operational taxonomic unit

Cyanobacteria, Deinococcus-Thermus, Firmicutes, Nitrospira, Planctomycetes, Spirochaetes, Verrucomicrobia and the candidate divisions WS3, TM6, OP1, OP3, OP8 and OP11. The diversity (Shannon's index), number of clones analysed, relative abun- 
Table 1. Distribution of 16S rRNA bacterial ribotypes within each phylum in DNA- and RNA-based analyses between upper $(0-50 \mathrm{~mm})$ and lower $(100-150 \mathrm{~mm})$ sediments at Sites A and B. The relative abundance $(\%)$ of clones for each phylum within a particular sample is based on forward partial sequences. The Shannon diversity index $\left(H^{\prime}\right)$ and the number of high quality partial sequences analysed (n) from each library is also presented. rDNA (rRNA): ribotypes from sediment-extracted DNA (RNA or cDNA) libraries

\begin{tabular}{|c|c|c|c|c|c|c|c|c|}
\hline \multirow[t]{3}{*}{ Phylum } & \multirow[t]{3}{*}{ Class } & \multirow[t]{3}{*}{ Order } & \multicolumn{4}{|c|}{ - Site A- } & \multicolumn{2}{|c|}{${ }_{-}$Site B } \\
\hline & & & \multicolumn{2}{|c|}{$0-50 \mathrm{~mm}$} & \multicolumn{2}{|c|}{$100-150 \mathrm{~mm}$} & \multirow{2}{*}{$\begin{array}{c}0-50 \mathrm{~mm} \\
\text { rDNA }\end{array}$} & \multirow{2}{*}{$\begin{array}{c}100-150 \mathrm{~mm} \\
\text { rDNA }\end{array}$} \\
\hline & & & rDNA & rRNA & rDNA & rRNA & & \\
\hline Proteobacteria & Alpha & & 0.0 & 0.0 & 0.0 & 0.0 & 2.4 & 1.4 \\
\hline Proteobacteria & Beta & Burkholderiales & 0.0 & 0.0 & 3.6 & 0.0 & 3.7 & 2.7 \\
\hline Proteobacteria & Beta & Methylophilales & 5.2 & 0.0 & 0.0 & 0.0 & 1.2 & 2.7 \\
\hline Proteobacteria & Beta & Unclassified & 0.0 & 0.0 & 3.6 & 1.3 & 2.4 & 2.7 \\
\hline Proteobacteria & Delta & Desulfobacterales & 13.0 & 3.4 & 18.1 & 1.3 & 9.8 & 13.5 \\
\hline Proteobacteria & Delta & Desulfuromonadales & 2.6 & 1.1 & 1.2 & 0.0 & 1.2 & 4.1 \\
\hline Proteobacteria & Delta & Myхососcales & 0.0 & 2.2 & 1.2 & 0.0 & 1.2 & 0.0 \\
\hline Proteobacteria & Delta & Syntrophobacterales & 11.7 & 4.5 & 8.4 & 6.5 & 6.1 & 6.8 \\
\hline Proteobacteria & Delta & Unclassified & 2.6 & 1.1 & 10.8 & 2.6 & 7.3 & 17.6 \\
\hline Proteobacteria & Gamma & Methylococcales & 11.7 & 6.7 & 7.2 & 1.3 & 7.3 & 5.4 \\
\hline Proteobacteria & Gamma & Pseudomonadales & 0.0 & 0.0 & 0.0 & 5.2 & 0.0 & 1.4 \\
\hline Proteobacteria & Gamma & Xanthomonadales & 2.6 & 2.2 & 0.0 & 0.0 & 0.0 & 2.7 \\
\hline Proteobacteria & Gamma & Legionellales & 0.0 & 0.0 & 0.0 & 0.0 & 0.0 & 1.4 \\
\hline Verrucomicrobia & & & 5.2 & 3.4 & 3.6 & 1.3 & 9.8 & 4.1 \\
\hline Acidobacteria & & & 7.8 & 9.0 & 9.6 & 20.8 & 7.3 & 4.1 \\
\hline Actinobacteria & & & 1.3 & 20.2 & 2.4 & 6.5 & 1.2 & 0.0 \\
\hline Firmicutes & & & 5.2 & 1.1 & 0.0 & 1.3 & 0.0 & 0.0 \\
\hline Chloroflexi & & & 3.9 & 11.2 & 1.2 & 7.8 & 2.4 & 0.0 \\
\hline Cyanobacteria & & & 0.0 & 2.2 & 0.0 & 5.2 & 1.2 & 0.0 \\
\hline Nitrospira & & & 0.0 & 0.0 & 3.6 & 1.3 & 8.5 & 2.7 \\
\hline Spirochaetes & & & 1.3 & 0.0 & 1.2 & 5.2 & 1.2 & 0.0 \\
\hline Planctomycetes & & & 3.9 & 3.4 & 2.4 & 1.3 & 1.2 & 8.1 \\
\hline Deinococcus-Thermu & & & 1.3 & 0.0 & 0.0 & 0.0 & 0.0 & 0.0 \\
\hline Cholorobi & & & 1.3 & 0.0 & 0.0 & 0.0 & 0.0 & 2.7 \\
\hline Bacteroidetes & & & 15.6 & 1.1 & 9.6 & 1.3 & 11.0 & 9.5 \\
\hline OP1 & & & 0.0 & 4.5 & 0.0 & 13.0 & 0.0 & 0.0 \\
\hline OP8 & & & 1.3 & 2.2 & 1.2 & 3.9 & 0.0 & 0.0 \\
\hline OP11 & & & 2.6 & 6.7 & 2.4 & 2.6 & 2.4 & 1.4 \\
\hline TM6 & & & 0.0 & 2.2 & 3.6 & 0.0 & 4.9 & 1.4 \\
\hline WS3 & & & 0.0 & 4.5 & 1.2 & 2.6 & 0.0 & 1.4 \\
\hline Unknown & & & 0.0 & 4.7 & 3.6 & 3.9 & 6.1 & 2.8 \\
\hline$H^{\prime}$ & & & 3.2 & 3.4 & 3.5 & 3.4 & 3.5 & 3.3 \\
\hline $\mathrm{n}=$ & & & 82 & 92 & 87 & 87 & 86 & 87 \\
\hline
\end{tabular}

dance and frequency of clones within each major phylogenetic division for each clone library are presented in Table 1.

\section{Archaeal community analysis}

A total of 570 clones from archaeal 16S rDNA and rRNA clone libraries were randomly sequenced, and 458 high quality partial sequences were obtained and grouped into 74 clusters. Representatives from each cluster were forward- and reverse-sequenced, and 51 OTUs were identified, based on a $97 \%$ cutoff. A total of 9 chimeras were detected and removed from the phylogenetic analysis. Almost $70 \%$ of the
16S rRNA gene sequences identified in the current study were affiliated with already existing sequences in the public databases with $97 \%$ identity (see Table S2 in the supplement at www.int-res.com/articles/suppl/a065p287_supp.pdf). These 16S rRNA

Fig. 5. Unrooted phylogenetic tree of proteobacterial 16S rRNA sequences from the current study and related reference sequences. Sequences from the current study are designated as Lake Wivenhoe, followed by the clone ID and GenBank accession number in brackets. The tree was constructed using the neighbour-joining method using nearly full-length aligned nucleotide sequences in MEGA version 4. Bootstrap values (\%) are based on 1000 replicates and are shown at the nodes with $>70 \%$ support. Scale bar represents $2 \%$ sequence divergence 


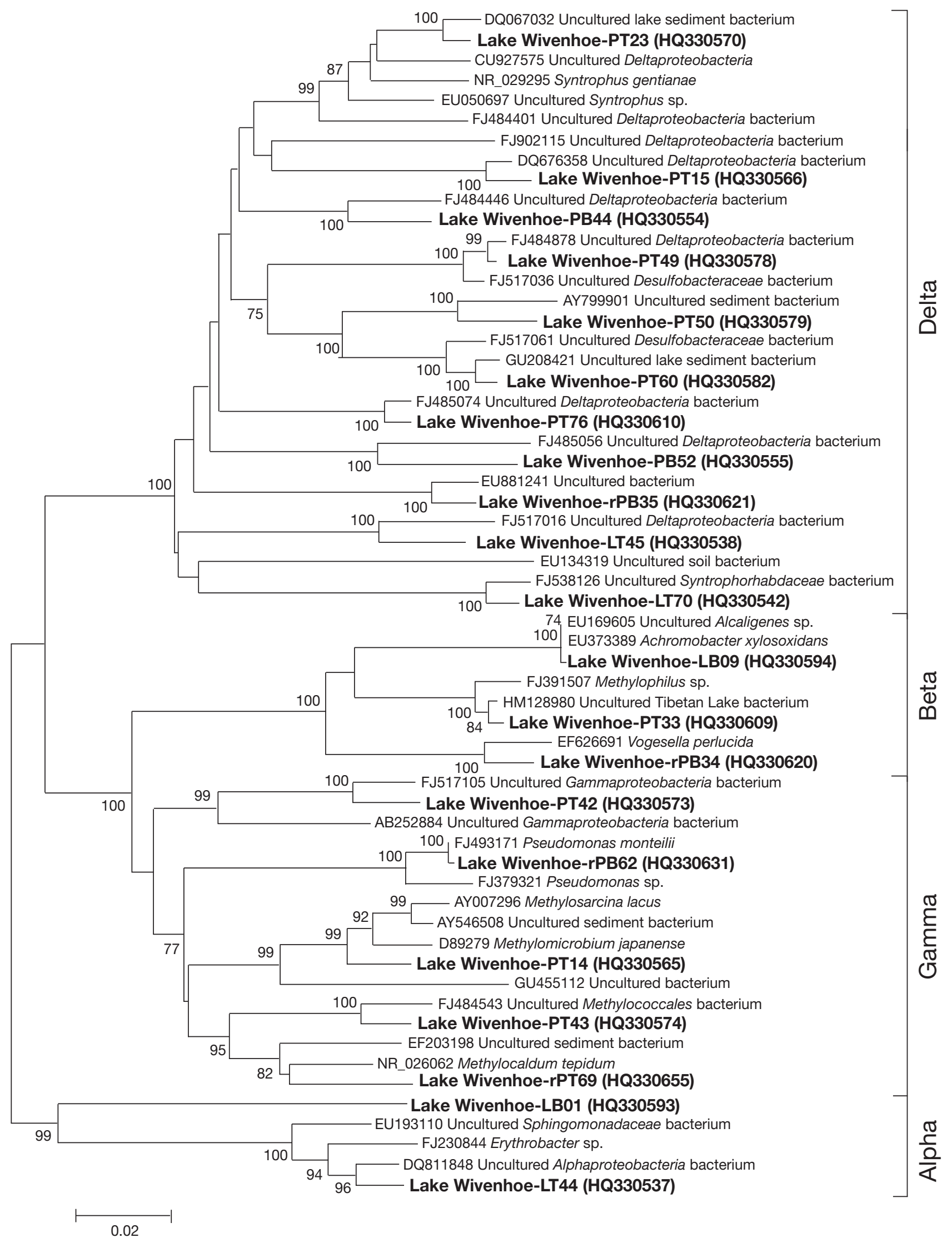




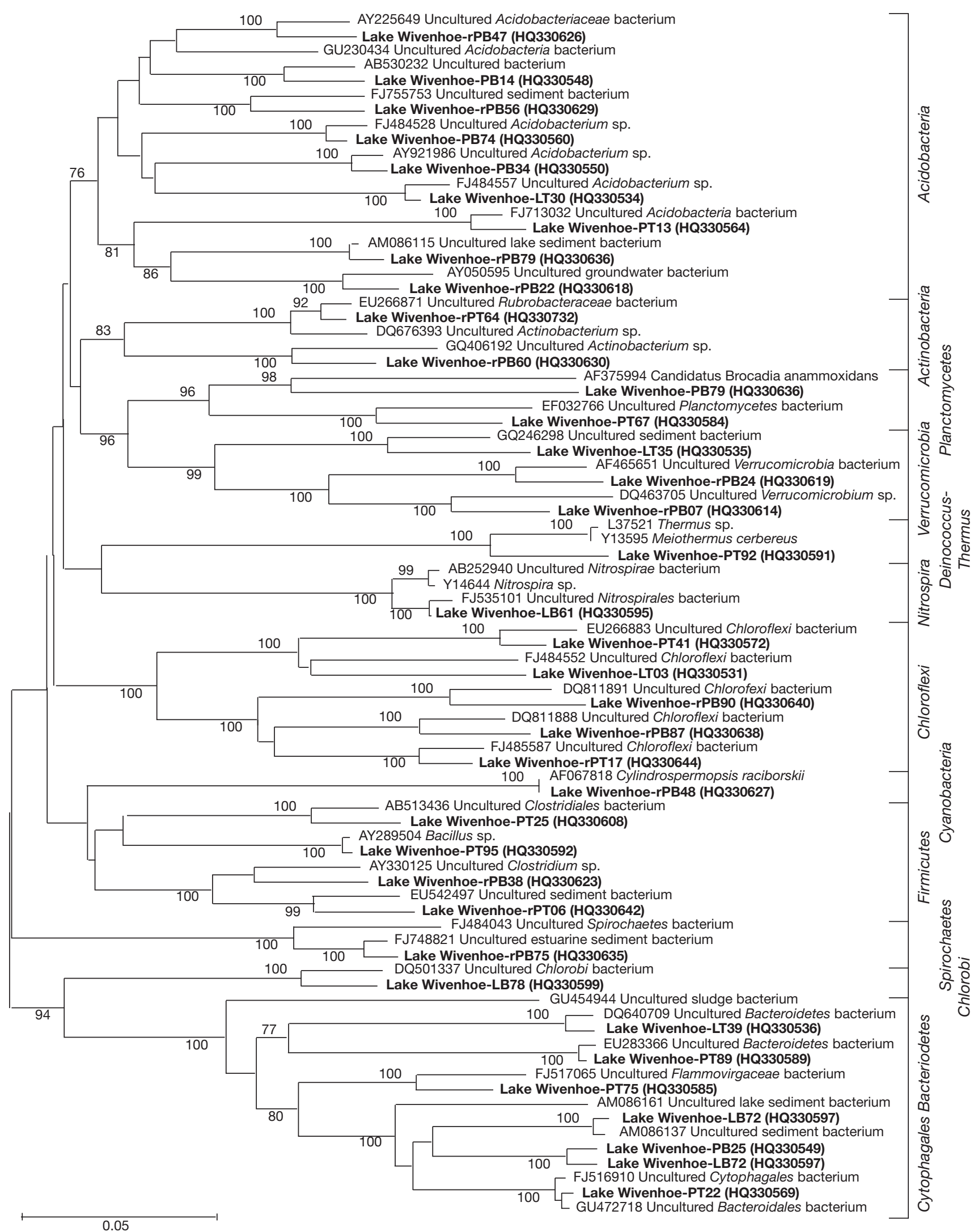

Fig. 6. Unrooted phylogenetic tree of classified bacterial 16S rRNA sequences, except those of Proteobacteria. For details see Fig. 5 legend. Scale bar represents $5 \%$ sequence divergence 


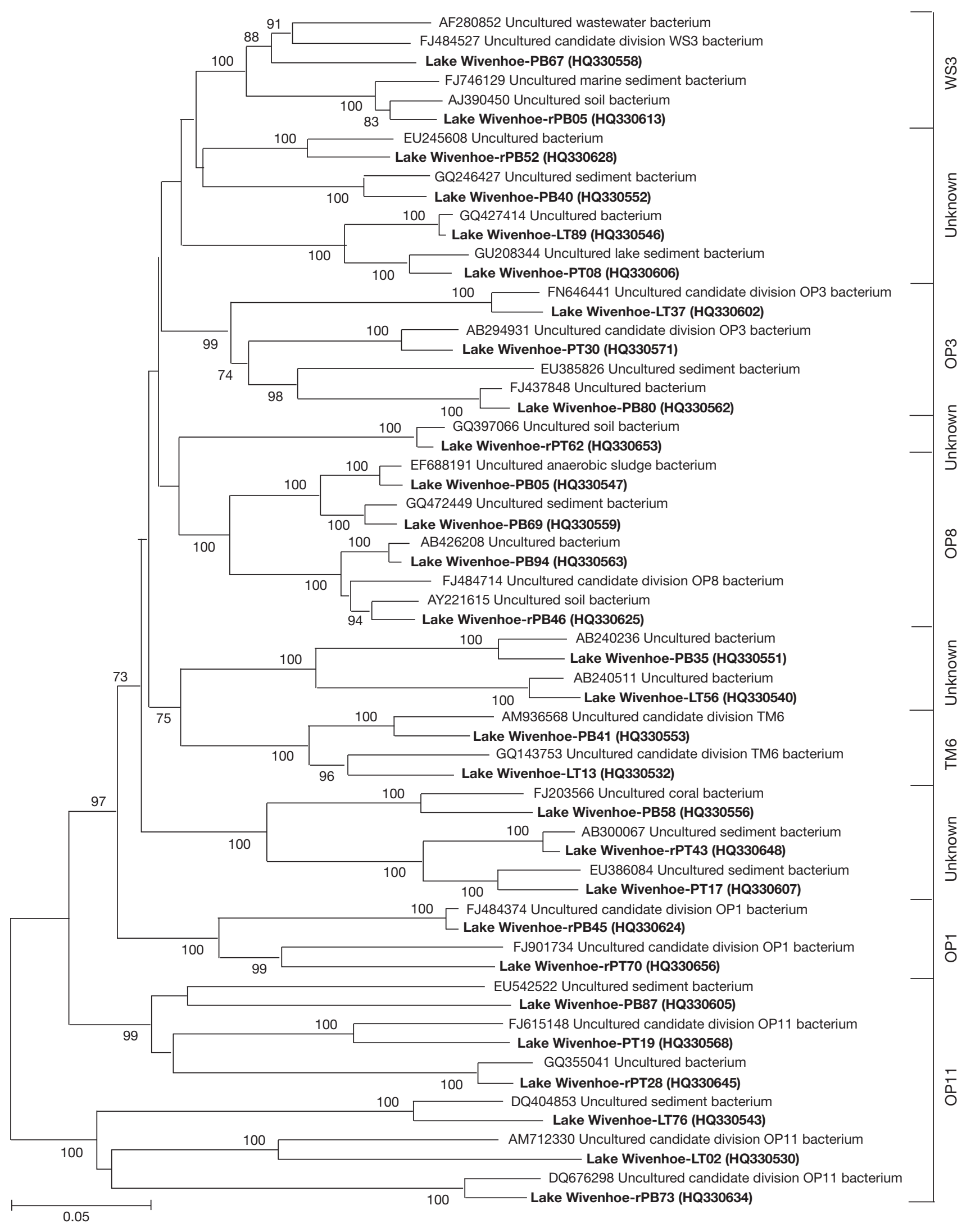

Fig. 7. Unrooted phylogenetic tree of unclassified bacterial 16S rRNA sequences retrieved in the current study. For details see Fig. 5 legend. Scale bar represents $5 \%$ sequence divergence 


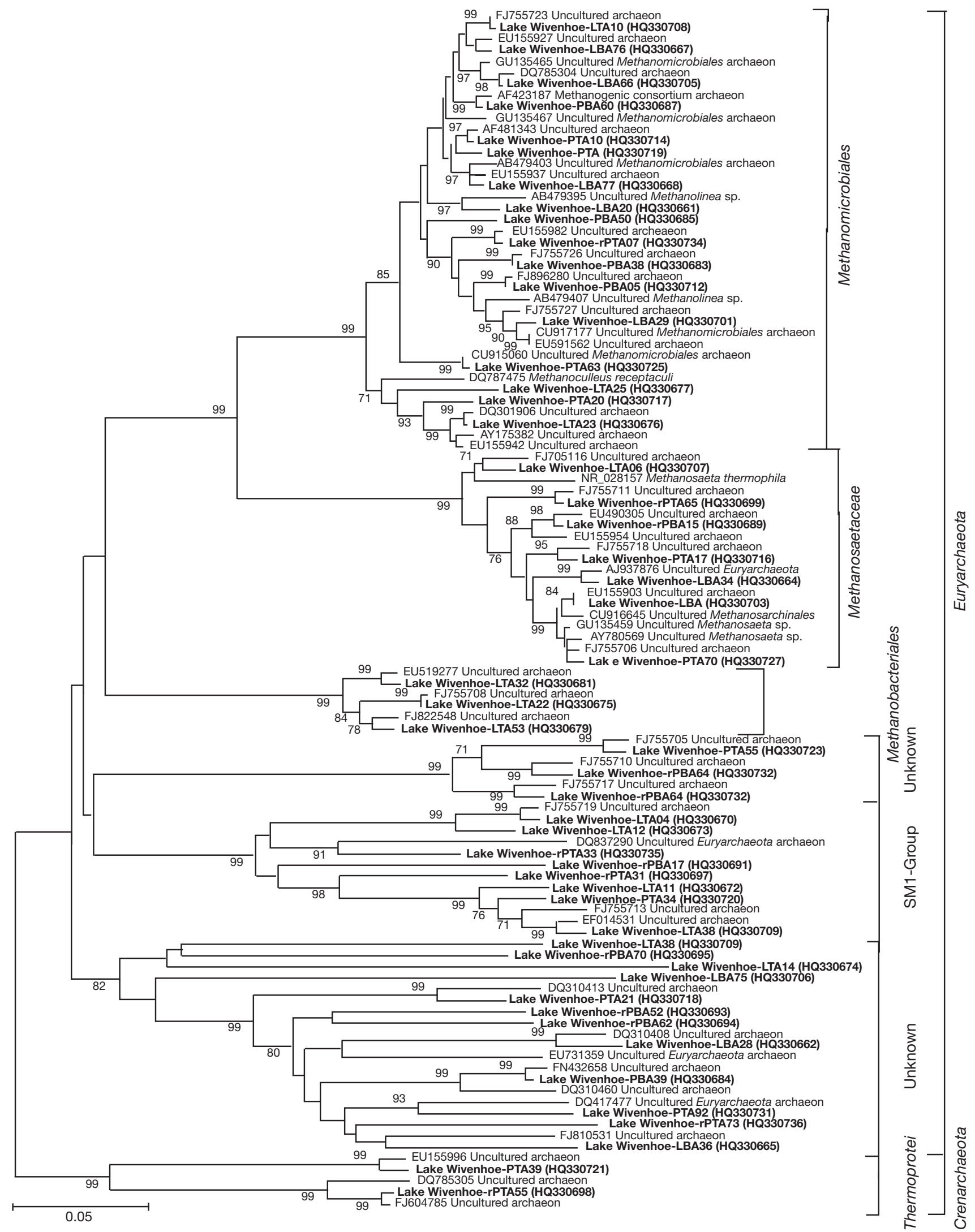

Fig. 8. Unrooted phylogenetic tree of archaeal 16S rRNA gene sequences retrieved in the current study and related reference sequences. For details see Fig. 5 legend. The scale bar represents $5 \%$ sequence divergence 
gene sequences had high similarities to those of uncultured methanogenic archaea (Fig. 8) retrieved from freshwater lake sediments (Lehours et al. 2007, Ye et al. 2009), wastewater sludge (Rivière et al. 2009), minerotrophic fen (Cadillo-Quiroz et al. 2008), acidic bogs (Chan et al. 2002) and peatlands (Basiliko et al. 2003, Cadillo-Quiroz et al. 2006). The remaining 24 sequences were remotely related to $16 \mathrm{~S}$ rRNA gene sequences of known archaea and represent novel phylotypes not described in previous studies (see Table S2 in the supplement). The majority of $16 \mathrm{~S}$ rRNA gene sequences in the current study belonged to either Methanomicrobiales or Methanosaeta, and the diversity, number of clones analysed and relative abundance of the major phylogenetic divisions in each archaeal 16S rDNA or rRNA clone library is presented in Table 2.

\section{Ammonia-oxidising archaea and bacteria}

Numerous attempts to amplify the archaeal and bacterial amoA gene from genomic DNA and cDNA isolated from Lake Wivenhoe sediment samples were unsuccessful. In each case, positive controls were successfully amplified. Additions of PCR enhancers (3 to $5 \%$ dimethyl sulfoxide in master mix) and modification of PCR parameters, such as annealing temperatures and number of cycles, were also unsuccessful for amplifying the amoA gene from Lake Wivenhoe samples.

\section{DISCUSSION}

The sediments of Lake Wivenhoe presumably contain organic material from the likely accumula- tion of autochthonous material (e.g. deceased phytoplankton) from the above surface waters. This organic material is utilised by a diverse microbial community for energy and cellular carbon and in the process is remineralised back into the water column. Although the temperature, $\mathrm{pH}$ and dissolved oxygen concentrations measured directly $(0.5 \mathrm{~m})$ above the water/sediment interface at the 2 study sites were only marginally different (Fig. 1), water column depth clearly influenced both nutrient flux rates (Fig. 2) and microbial community structure (Tables $1 \& 2$ ). At Site A, the measured dissolved oxygen penetrated to a water depth of $18 \mathrm{~m}$, which is approximately $11 \mathrm{~m}$ above the water/ sediment interface. In contrast, Site B is shallower (15 $\mathrm{m})$, and diffused dissolved oxygen would reach the water/sediment interface and be rapidly consumed by the sediment microbial community (Fig. 1). This supply of dissolved oxygen to the sediments at Site B would alter the metabolism and structure of the sediment microbial community. The following discussion speculates on the biogeochemical processes performed by the different members of bacteria and archaea observed in the sediments cores collected from the 2 different locations and how these microbial communities influence the remineralisation and flux of nutrients known to be involved in phytoplankton blooms.

\section{Microbial diversity}

The current study identified a total of 87 bacteria and 57 archaea in the upper and lower sediments of Lake Wivenhoe. However, the true bacterial and archaeal diversity within the sediments is still likely to be underestimated, as indicated by rarefaction

Table 2. Distribution of $16 \mathrm{~S}$ rRNA archaea ribotypes within each phylum in DNA- and RNA-based analyses between upper and lower sediments at Sites A and B. The relative abundance of clones for each group within a particular sample is presented as a percentage. Shannon diversity index $\left(H^{\prime}\right)$ and the number of high quality partial sequences analysed (n) from each library is also presented. rDNA (rRNA): ribotypes from sediment-extracted DNA (RNA or cDNA) libraries

\begin{tabular}{|c|c|c|c|c|c|c|c|c|}
\hline \multirow{3}{*}{ Phylum } & \multirow{3}{*}{ Class } & \multirow{3}{*}{ Order } & \multicolumn{4}{|c|}{ - Site A } & \multicolumn{2}{|c|}{$\longrightarrow$ Site B } \\
\hline & & & \multicolumn{2}{|c|}{$0-50 \mathrm{~mm}$} & \multicolumn{2}{|c|}{$100-150 \mathrm{~mm}$} & \multirow{2}{*}{$\begin{array}{c}0-50 \mathrm{~mm} \\
\text { rDNA }\end{array}$} & \multirow{2}{*}{$\begin{array}{c}100-150 \mathrm{~mm} \\
\text { rDNA }\end{array}$} \\
\hline & & & rDNA & rRNA & rDNA & rRNA & & \\
\hline Crenarchaeota & Thermoprotei & & 1.1 & 2.1 & 0.0 & 1.1 & 0.0 & 0.0 \\
\hline Euryarchaeota & Methanobacteria & Methanobacteriales & 2.2 & 2.1 & 1.1 & 0.0 & 3.2 & 4.3 \\
\hline Euryarchaeota & Methanomicrobia & Methanomicrobiales & 53.8 & 48.9 & 69.0 & 57.8 & 50.5 & 49.5 \\
\hline Euryarchaeota & Methanomicrobia & Methanosarcinales & 35.2 & 26.6 & 27.6 & 21.1 & 34.7 & 41.9 \\
\hline Unknown & & & 7.7 & 20.2 & 2.3 & 20.0 & 11.6 & 4.3 \\
\hline$H^{\prime}$ & & & 2.9 & 3.2 & 2.8 & 3.2 & 3.1 & 3.1 \\
\hline $\mathrm{n}$ & & & 91 & 94 & 87 & 90 & 95 & 93 \\
\hline
\end{tabular}


curves, which do not reach a diversity plateau (Fig. 4). Despite this, the bacterial and archaeal diversity (based on the Shannon index) was high and ranged from 3.2 to 3.5 and 2.8 to 3.2 , respectively, in the sediments of Lake Wivenhoe (Tables 1 \& 2). The obtained diversity values in the current study are similar to those of other studies investigating sediment communities using similar techniques (Briée et al. 2007, Schwarz et al. 2007).

\section{Role of microbes in biogeochemical cycling}

Dissolved reactive silica fluxes were greater from sediment cores collected at Site A (Fig. 2), which was supported by a significantly higher silica concentration in the bottom waters at this site (Fig. S2 in the supplement at www.int-res.com/articles/suppl/a065 p287_supp.pdf). The sediments of Lake Wivenhoe presumably contain biogenic silica from the sedimentation of deceased diatoms. Remineralisation of biogenic silica is largely controlled by abiotic factors (Conley et al. 1993), but microbes can enhance the dissolution of biogenic silica by removing organic coatings from diatom frustules (Libes 2009). Degradation of organic matter within the sediments requires multiple steps performed by different trophic levels of bacteria and archaea. Heterotrophs are responsible for the initial microbial degradation of complex organic material within the sediments and therefore fill the lowest trophic level. These heterotrophs utilize this complex organic material for energy and cellular carbon and excrete a range of simple organic (e.g. acetate) and inorganic (e.g. urea and ammonia) molecules, which are then further catabolised by higher trophic levels of chemolithotrophs. Acetate can be assimilated into cellular carbon and further metabolised to methane and $\mathrm{CO}_{2}$ by acetoclastic methanogenesis or completely oxidised to $\mathrm{CO}_{2}$ by sulphate-reducing bacteria (Winfrey \& Zeikus 1977).

Actinobacteria and Acidobacteria were likely to be the most metabolically active heterotrophic bacteria within the upper and lower sediments, respectively, of Lake Wivenhoe based on the frequency of 16S rRNA ribotypes in clone libraries. Other heterotrophs, including Verrucomicrobia, Firmicutes and Pseudomonas sp., were also identified in the $16 \mathrm{~S}$ rDNA libraries and hence may also participate in the degradation of organic material. Actinobacteria constitute a diverse phylum, with members possessing highly variable physiological and metabolic properties, and are abundant in environmental soil and sediment samples (Ventura et al. 2007). Actinobacteria play an important role in carbon cycling and have been shown to excrete a wide range of enzymes that degrade complex organic carbons (lignin) during composting of agricultural waste (Yu et al. 2007). Actinobacteria in the upper sediments of Lake Wivenhoe may play an important role in removing the complex polysaccharide coatings from diatom frustules and exposing biogenic silica to under-saturated waters.

Sulphate reduction is thought to outcompete methanogenesis when sulphate is freely available because cultured strains of sulphate-reducing bacteria have higher specific affinities than methanogenic bacteria and archaea for the main substrates (acetate and $\mathrm{H}_{2}$ ) used by both groups (Purdy et al. 2003). However, available sulphate is usually limiting in freshwater environments, resulting in the dominance of methanogenesis as the main microbial pathway for organic carbon degradation in freshwater systems (Purdy et al. 2003). The high relative abundance of both sulphate-reducing bacteria and methanogenic archaea within the $16 \mathrm{~S}$ rRNA clone libraries suggests that both of these microbial pathways do occur in the sediments of Lake Wivenhoe (Table 1). Sulphate-reducing bacteria (Desulfobacterales, Desulfuromonadales and Syntrophobacterales) were the most frequently observed ribotypes in 16S rDNA clone libraries from Sites A and B (Table 1). However, sulphate-reducing bacteria were likely to be metabolically inactive at the time of sampling based on the ratio of $16 \mathrm{~S}$ rRNA to $16 \mathrm{~S}$ rDNA sequences observed (Table 1). Sulphate reduction and methanogenesis can occur simultaneously in anoxic, sulphate-containing sediments if methanogens utilise substrates (e.g. methanol) not required by sulphate reducers (Oremland \& Polcin 1982), or production of methane occurs from methanogenic $\mathrm{CO}_{2}$ reduction by syntrophic consortia of acetate-oxidising bacteria and $\mathrm{H}_{2} / \mathrm{CO}_{2}$-using methanogens (Nüsslein et al. 2001). The majority of archaea identified in the present study had 16S rRNA sequences related to Methanomicrobiales (49 to 69\%), Methanosaeta (21 to $41 \%$ ) and Methanobacterium (2 to $4 \%$ ), suggesting that methane is produced in the sediments of Lake Wivenhoe by both methanogenic $\mathrm{H}_{2} / \mathrm{CO}_{2}$ reduction (via Methanomicrobiales and Methanobacterium) and acetoclastic methanogenesis (via Methanosaeta) (Chan et al. 2002). Complete degradation of organic carbon in freshwater sediments by a syntrophic partnership of hydrogenotrophic and acetoclastic methanogens was recently suggested by 
Biderre-Petit et al. (2011) and also appears to be the case in Lake Wivenhoe.

The measured flux of methane from the sediments of Site A was almost 4 -fold greater than at Site B (Fig. 3). Increased methane production at Site A may be the result of a higher abundance or metabolic rate of methanogenic archaea, but methane is more likely being oxidised at the water-sediment interface at Site B. In freshwater environments, methane is usually oxidised at the oxic/anoxic interface by aerobic bacteria (Segers 1998). The diffusion of dissolved oxygen to the water/sediment interface at Site B presumably allows aerobic methane oxidation to occur by Methylococcales ribotypes (Type I methanotrophs), which were observed in 16S rRNA clone libraries. Methane can also be oxidised by anaerobic methane-oxidising archaea (ANME), which have been identified from the anoxic water body of the eutrophic freshwater Lake Plußsee (Eller et al. 2005). In the marine environment, anaerobic methane oxidation is reportedly coupled to sulphate reduction (Thomsen et al. 2001). No evidence exists to suggest this pathway occurs in freshwater systems (Knittel \& Boetius 2009), and anaerobic methane oxidation in freshwater environments may instead be coupled with reduction of nitrite to dinitrogen (Ettwig et al. 2010). No 16S rRNA sequences related to ANME were retrieved in the current study.

The efflux of FRP was greater from the cores collected from Site A. Studies have shown that $\mathrm{PO}_{4}{ }^{3-}$ cycling in freshwater lakes is regulated by the availability of and complexation with oxidised iron (Kleeberg 1997). The sediments of lakes with oxic hypolimnia contain oxidised iron $\left(\mathrm{Fe}^{3+}\right)$, as $\mathrm{FePO}_{4}$, and related hydroxides (Murray 1995). As thermal stratification occurs, the hypolimnion becomes anoxic, and the reductive dissolution of $\mathrm{Fe}^{3+}$ releases ferrous $\mathrm{Fe}^{2+}$ and $\mathrm{PO}_{4}{ }^{3-}$ into the water column (Murray 1995). Our study identified a wide range of microorganisms in the sediments of Lake Wivenhoe that are capable of reducing $\mathrm{Fe}^{3+}$ for energy and growth, including members within sulphur-reducing bacteria, methanogenic archaea, Acidobacteria and Deinococcus-Thermus (Lovley et al. 2004). The greater efflux of FRP at Site A is most likely the result of the fully anoxic conditions at this site allowing a higher abundance and/or metabolic activity of $\mathrm{Fe}^{3+}$ reducers.

Decomposition of phytoplankton in the sediments generates ammonia primarily from the deamination of amino acids and urea (Jones et al. 1982). Ammonia is converted to nitrate in a 2-step process termed 'nitrification', which is performed by 2 distinct groups of aerobic chemolithoautotrophic microbes. One step oxidises ammonia to nitrite (conducted by ammoniaoxidising bacteria or archaea), whereas another group oxidises nitrite to nitrate (Arp \& Stein 2003). The fully anoxic conditions at Site A did not support nitrification, and $>97 \%$ of the nitrogen efflux at this site was ammonia. In contrast, the supply of dissolved oxygen to the water/sediment interface at Site B supported nitrification, with $100 \%$ of the nitrogen efflux as nitrate (Fig. 2). The frequency of Nitrospira ribotypes (aerobic nitrite oxidisers) was also highest in the upper sediment clone library from Site B, suggesting that Nitrospira ribotypes play an important role in nitrite oxidation in Lake Wivenhoe. However, the microbes responsible for ammonia oxidation at Site B could not be determined in the current study. Most ammonia-oxidising bacteria (AOB) fall within the Nitrosomonas order of the Betaproteobacteria (Arp \& Stein 2003), which were not detected in the 16S rDNA libraries in the present study. Recently, ammonia-oxidising archaea (AOA) were discovered and have been identified in the water column and sediments of freshwater lakes (Pouliot et al. 2009, Ye et al. 2009). These AOA belong to the Crenarchaeota phylum and are known to occur within the suboxic zone $\left(<0.32 \mathrm{mg} \mathrm{l}^{-1}\right.$ of dissolved oxygen) (Coolen et al. 2007). Attempts to identify AOA and AOB by amplifying the $a m o A$ gene were unsuccessful, suggesting that ammonia oxidation is possibly performed instead by ammonia-oxidising heterotrophs (e.g. Alcaligenes spp.) or methane oxidisers (e.g. Methylococcales), and further research is warranted to determine if these heterotrophs are responsible for ammonia oxidation in the sediments of Lake Wivenhoe.

Ammonia could also be oxidised anaerobically with nitrite to dinitrogen (anammox) within the sediments of Lake Wivenhoe by bacteria falling in the order of Planctomycetales (Jetten et al. 2003). Planctomycete phylotypes related to environmental sequences were identified in the present study, with their highest relative abundance in the lower sediments of Site B. However, because Planctomycetales are physiologically diverse, it is not possible to comment on whether the planctomycete phylotypes identified in the sediments of Lake Wivenhoe are indeed involved in anammox. Theoretically, anaerobic ammonia oxidation can also be coupled to manganese or iron reduction to produce nitrite or dinitrogen (Feammox) (Hulth et al. 1999), but this pathway is yet to be quantified in nature. Nitrite production has been observed under Fe-reducing conditions in wetland sediments, suggesting that Feammox could exist in sediments (reviewed by Burgin et al. 2011). 


\section{CONCLUSIONS}

Our study has contributed to the overall understanding of the role that microorganisms play in nutrient remineralisation in freshwater sediments. Although the type of analysis carried out here cannot quantify the abundance of bacteria and archaea in the sediments of Lake Wivenhoe, it constitutes the basis for assessing the relative importance of specific groups in nutrient remineralisation and carbon processing. Our results demonstrated that physicochemical properties of the water column (depth of water column and diffusion of dissolved oxygen) influenced the sediment microbial community structure. Furthermore, our study showed that the bacteria present in the sediments (based on 16S rDNA ribotypes) were not necessarily metabolically active (based on $16 \mathrm{~S}$ rRNA ribotypes) at the time of sampling. Differences in the observed sediment flux rates and speciation of nutrients between the 2 study sites was likely the result of differences in the metabolic processes performed by the corresponding microbial communities. Differences in the flux and speciation of these nutrients released from the sediments into the hypolimnion could influence phytoplankton species composition and bloom dynamics when the hypolimnion mixes with the epilimnion during overturn. Future research should focus on quantifying and measuring the metabolic processes performed by individual members within the microbial community to assess their individual roles in nutrient biogeochemical cycling.

Acknowledgements. The authors acknowledge the financial and in-kind support provided by Queensland Bulk Water Supply Authority, trading as Seqwater. The authors also acknowledge the assistance of $\mathrm{N}$. Cutts and members of Seqwater's monitoring team during fieldwork.

\section{LITERATURE CITED}

> Altschul SF, Madden TL, Schaffer AA, Zhang J, Zhang Z, Miller W, Lipman DJ (1997) Gapped blast and psi-blast: A new generation of protein database search programs. Nucleic Acids Res 25:3389-3402

> Arp DJ, Stein LY (2003) Metabolism of inorganic N compounds by ammonia-oxidizing bacteria. Crit Rev Biochem Mol Biol 38:471-495

> Ashelford KE, Chuzhanova NA, Fry JC, Jones AJ, Weightman AJ (2006) New screening software shows that the most recent large 16S rRNA gene clone libraries contain chimeras. Appl Environ Microbiol 72:5734-5741

Basiliko N, Yavitt JB, Dees PM, Merkel SM (2003) Methane biogeochemistry and methanogen communities in two northern peatland ecosystems, New York State. Geomicrobiol J 20:563-577
Beutel MW (2006) Inhibition of ammonia release from anoxic profundal sediments in lakes using hypolimnetic oxygenation. Ecol Eng 28:271-279

Beutel MW, Leonard TM, Dent SR, Moore BC (2008) Effects of aerobic and anaerobic conditions of $\mathrm{P}, \mathrm{N}, \mathrm{Fe}, \mathrm{Mn}$, and $\mathrm{Hg}$ accumulation in waters overlaying profundal sediments of an oligo-mesotrophic lake. Water Res 42: 1953-1962

- Biderre-Petit C, Jézéquel D, Dugat-Bony E, Lopes F and others (2011) Identification of microbial communities involved in the methane cycle of a freshwater meromictic lake. FEMS Microbiol Ecol 77:533-545

Briée C, Moreira D, Lopez-Garcia P (2007) Archaeal and bacterial community composition of sediment and plankton from a suboxic freshwater pond. Res Microbiol 158: 213-227

Burford MA, McNeale KL, McKenzie-Smith FJ (2006) The role of nitrogen in promoting the toxic cyanophyte Cylindrospermopsis raciborskii in a subtropical water reservoir. Freshw Biol 51:2143-2153

Burford M, Green SA, Cook AJ, Johnson SA, Kerr JG, O'Brian KR (2012) Sources and fate of nutrients in a subtropical reservoir. Aquat Sci 74:179-190

Burgin AJ, Yang WH, Hamilton SK, Silver WL (2011) Beyond carbon and nitrogen: how the microbial energy economy couples elemental cycles in diverse ecosystems. Front Ecol Environ 9:44-52

> Cadillo-Quiroz H, Bräuer S, Yashiro E, Sun C, Yavitt J, Zinder S (2006) Vertical profiles of methanogenesis and methanogens in two contrasting acidic peatlands in Central New York State, USA. Environ Microbiol 8: 1428-1440

> Cadillo-Quiroz H, Yashiro E, Yavitt JB, Zinder SH (2008) Characterization of the archaeal community in a minerotrophic fen and terminal restriction fragment length polymorphism-directed isolation of a novel hydrogenotrophic methanogen. Appl Environ Microbiol 74:2059-2068

Chan OC, Wolf M, Hepperle D, Casper P (2002) Methanogenic archaeal community in the sediment of an artificially partitioned acidic bog lake. FEMS Microbiol Ecol 42:119-129

Conley DJ, Schelske CL, Stoermer EF (1993) Modification of the biogeochemical cycle of silica with eutrophication. Mar Ecol Prog Ser 101:179-192

> Coolen MJL, Abbas B, van Bleijswijk J, Hopmans EC, Kuypers MMM, Wakeham SG, Sinninghe Damsté JS (2007) Putative ammonia-oxidising Crenarchaeota in suboxic waters of the black sea: a basin-wide ecological study using 16S ribosomal and functional genes and membrane lipids. Environ Microbiol 9:1001-1016

Correll DL (1998) The role of phosphorus in the eutrophication of receiving waters: a review. J Environ Qual 27: 261-266

> D'Auria G, Barón-Rodríguez MM, Durbán-Vicente A, Moya A, Rojo C, Latorre A, Rodrigo MA (2010) Unravelling the bacterial diversity found in the semi-arid Tablas de Daimiel National Park wetland (Central Spain). Aquat Microb Ecol 59:33-44

> Douglas G, Palmer M, Caitcheon G, Orr P (2007) Identification of sediment sources to Lake Wivenhoe, southeast Queensland, Australia. Mar Freshw Res 58:793-810

> Eller G, Känel L, Krüger M (2005) Cooccurence of aerobic and anaerobic methane oxidation in the water column of Lake Plußsee. Appl Environ Microbiol 71:8925-8928 
Ettwig KF, Butler MK, Paslier DL, Pelletier E and others (2010) Nitrite-driven anaerobic methane oxidation by oxygenic bacteria. Nature 464:543-548

Eyre BD, Ferguson AJP (2002) Comparison of carbon production and decomposition, benthic nutrient fluxes and denitrification in seagrass, phytoplankton, benthic microalgae- and macroalgae-dominated warm-temperate Australian lagoons. Mar Ecol Prog Ser 229:43-59

Francis CA, Roberts KJ, Bemen MJ, Santoro AE, Oakley BB (2005) Ubiquity and diversity of ammonia-oxidizing archaea in water columns and sediments of the ocean. Proc Natl Acad Sci USA 102:14683-14688

> Huber T, Faulkner G, Hugenholtz P (2004) Bellerophon: a program to detect chimeric sequences in multiple sequence alignments. Bioinformatics 20:2317-2319

> Hulth S, Aller RC, Gilbert F (1999) Coupled anoxic nitrification/manganese reduction in marine sediments. Geochim Cosmochim Acta 63:49-66

> Jetten MSM, Slieker O, Kuypers M, Dalsgaard T and others (2003) Anaerobic ammonium oxidation by marine and freshwater planctomycete-like bacteria. Appl Microbiol Biotechnol 63:107-114

> Jiang L, Zheng Y, Peng X, Zhou H, Zhang C, Xiao X, Wang F (2009) Vertical distribution and diversity of sulfatereducing prokaryotes in the Pearl River estuarine sediments, Southern China. FEMS Microbiol Ecol 70: $249-262$

Jones JG, Simon BM, Horsley RW (1982) Microbiological sources of ammonia in freshwater lake sediments. J Gen Microbiol 128:2823-2831

Kerr JG, Burford M, Olley J, Udy J (2010) Phosphorus sorption in soils and sediments: implications for phosphate supply to a subtropical river in Southeast Queensland, Australia. Biogeochemistry 102:73-85

Kerr JG, Burford M, Olley J, Udy J (2011a) Nitrogen and phosphorus storage in contrasting reaches of a sub-tropical river system. Water Air Soil Pollut 217:523-534

Kerr JG, Burford M, Olley J, Bunn S, Udy J (2011b) Examining the link between terrestrial and aquatic phosphorus speciation in a subtropical catchment: the role of selective erosion and transport of the sediments during storm events. Water Res 45:3331-3340

Klausen C, Jørgensen NOG, Burford M, O'Donohue M (2004) Actinomycetes may also produce taste and odour. Vatten 31:45-49

Kleeberg A (1997) Interactions between benthic phosphorus release and sulfur cycling in Lake Scharmutzelsee (Germany). Water Air Soil Pollut 99:391-399

Knittel K, Boetius A (2009) Anaerobic oxidation of methane: progress with an unknown process. Annu Rev Microbiol 63:311-334

Lehours AC, Evan P, Bardot C, Joblin K, Gerard F (2007) Phylogenetic diversity of archaea and bacteria in the anoxic zone of a meromictic lake (Lake Pavin, France). Appl Environ Microbiol 73:2016-2019

Libes SM (2009) Biogenic silica. In: Libes SM (ed) Introduction to marine biogeochemistry. Elsevier, Burlington, MA, p 403-422

> Lovley DR, Holmes DE, Nevin KP (2004) Dissimilatory Fe(III) and Mn (IV) reduction. Adv Microb Physiol 49:219-286

> Miskin IP, Farrimond P, Head IM (1999) Identification of novel bacterial lineages as active members of microbial populations in a freshwater sediment using a rapid RNA extraction procedure and RT-PCR. Microbiology 145: 1977-1987
Murray TE (1995) The correlation between iron sulfide precipitation and hypolimnetic phosphorus accumulation during one summer in a softwater lake. Can J Fish Aquat Sci 52:1190-1194

Nüsslein B, Chin KJ, Eckert W, Conrad R (2001) Evidence for anaerobic syntrophic acetate oxidation during methane production in the profundal sediment of subtropical Lake Kinneret (Israel). Environ Microbiol 3: 460-470

O'Sullivan CA, Burrell PC, Clarke WP, Blackall LL (2005) Structure of a cellulose degrading bacterial community during anaerobic digestion. Biotechnol Bioeng 92: 871-878

> Oremland RS, Polcin S (1982) Methanogenesis and sulfate reduction: competitive and noncompetitive substrates in estuarine sediments. Appl Environ Microbiol 44: 1270-1276

> Posselt AJ, Burford MA, Shaw G (2009) Pulses of phosphate promote dominance of the toxic cyanophyte Cylindrospermopsis raciborskii in a subtropical water reservoir. J Phycol 45:540-546

> Pouliot J, Galand PE, Lovejoy C, Vincent WF (2009) Vertical structure of archaeal communities and the distribution of ammonia monooxygenase a gene variants in two meromictic high artic lakes. Environ Microbiol 11:687-699

Purdy KJ, Nedwell DB, Embley TM (2003) Analysis of the sulfate-reducing bacterial and methanogenic archaeal populations in contrasting Antarctic sediments. Appl Environ Microbiol 69:3181-3191

> Rivière D, Desvignes V, Pelletier E, Chaussonnerie S and others (2009) Towards the definition of a core of microorganisms involved in anaerobic digestion of sludge. ISME J 3:700-714

Rotthauwe JH, Witzel KP, Liesack W (1997) The ammonia monooxygenase structural gene amoA as a functional marker: molecular fine-scale analysis of natural ammonia-oxidizing populations. Appl Environ Microbiol 63: 4704-4712

Sahl JW, Fairfield N, Harris JK, Wettergreen D, Stone WC, Spear JR (2010) Novel microbial diversity retrieved by autonomous robotic exploration of the world's deepest vertical phreatic sinkhole. Astrobiology 10:201-213

Saitou N, Nei M (1987) The neighbour-joining method: a new method for reconstructing phylogenetic trees. Mol Biol Evol 4:406-425

Schwarz JIK, Eckert W, Conrad R (2007) Community structure of archaea and bacteria in a profundal lake sediment Lake Kinneret (Israel). Syst Appl Microbiol 30: 239-254

Segers R (1998) Methane production and methane consumption: a review of processes underlying wetland methane fluxes. Biogeochemistry 41:23-51

Tamura K, Dudley J, Nei M, Kumar S (2007) MEGA4: molecular evolutionary genetics analysis (MEGA) software version 4.0. Mol Biol Evol 24:1596-1599

> Thomsen TR, Finster K, Ramsing NB (2001) Biogeochemical and molecular signatures of anaerobic methane oxidation in a marine sediment. Appl Environ Microbiol 67: 1646-1656

- Ventura M, Canchaya C, Tauch A, Chandra G, Fitzgerald GF, Chater KF, van Sinderen D (2007) Genomics of Actinobacteria: tracing the evolutionary history of an ancient phylum. Microbiol Mol Biol Rev 71:495-548

> Winfrey MR, Zeikus JG (1977) Effect of sulfate on carbon and electron flow during microbial methanogenesis in fresh- 
water sediments. Appl Environ Microbiol 33:275-281

Ye W, Liu X, Lin S, Tan J, Pan J, Li D, Yang H (2009) The vertical distribution of bacterial and archaeal communities in the water and sediment of Lake Taihu. FEMS Microbiol Ecol 70:263-276

Yu H, Zeng G, Huang H, Xi X, Wang R, Huang D, Huang G,

Editorial responsibility: Rutger de Wit, Montpellier, France
Li J (2007) Microbial community succession and lignocellulose degradation during agricultural waste composting. Biodegradation 18:793-802

Zaitlin B, Watson SB (2006) Actinomycetes in relation to taste and odour in drinking water: myths, tenets and truths. Water Res 40:1741-1753

Submitted: July 20, 2011; Accepted: December 20, 2011 Proofs received from author(s): February 29, 2012 